\title{
Development Strategy to Improve Class Classification in Nusantara Fishery Port Pengambengan, Bali Province
}

\author{
I Gede Suyoga ${ }^{1}$, I Wayan Restu ${ }^{2}$, I Ketut Wija Negara ${ }^{3}$, Bagus Sudananjaya ${ }^{4}$ \\ ${ }^{1}$ Department of Aquatic Resources Management, Faculty of Marine and Fisheries, Udayana University \\ Jl. Kampus Unud Bukit Jimbaran, Kuta Selatan, Badung, Bali \\ *Corresponding author: yogasuyoga98@gmail.com
}

\begin{abstract}
In the framework of improving governance, functional dimensions and performance of the fishing port, the Nusantara Fishery Port in Jembrana Bali compiles a "strategic plan" to improve the class classification of the Nusantara Fishing Port Pengambengan to become a class A Ocean Fishing Port, a number of management facility criteria are required as the main prerequisites. The purpose of this study was to determine the condition of the facilities at Nusantara Fishing Port Pengambengan and to determine the strategy for developing a fishing port at Nusantara Fishing Port Pengambengan. This research method uses descriptive qualitative and quantitative methods. Data collection techniques through direct observation and interviews using a questionnaire regarding the condition of the facilities at Nusantara Fishing Port Pengambengan, then data analysis using a SWOT analysis approach. Nusantara Pengambengan Fishery Port is a class B port that functions as a support for the management and utilization of fish resources and the environment, starting from pre-production, production, processing and marketing of fishery products. In supporting fishery activities, Nusantara Fishing Port Pengambengan is currently supported by various facilities, namely basic facilities, functional facilities, and supporting facilities. The results showed that there were several facilities in poor conditions, namely basic pier facilities, anchoring ponds, complex roads and drainage, from supporting facilities, namely public toilets and guest houses. Several facilities are not available in the Nusantara Fishing Port Pengambengan construction, namely ship docks, net repair wards/places, laboratories, WWTPs, watchtowers, and perimeter fences. The strategies obtained from the results of this study include: (1) Improving the quality of the catch to provide a positive image for potential investors. (2) Improve administrative services to provide fishermen comfort when carrying out fishing operations. (3) Support is needed, especially the role of the government related to management and development.
\end{abstract}

Keywords: Nusantara fishing port Pengambengan, facility conditions, development strategy.

\section{INTRODUCTION}

Fishery port is a combination area between land and sea areas which is used as a base for fishing activities and is equipped with various facilities, then the management of fishery activities starts from the landed fish until the fish is distributed, the role of the port here as the provision of facilities and infrastructure including the provision of facilities and services [11]. Based on Law number 45 of 2009 concerning Fisheries, it states that a fishing port is a place consisting of land and waters around it with certain boundaries as a place for government activities and fisheries business system activities that are used as a place for fishing boats to dock, and unload fish. Equipped with shipping safety facilities and fishery support activities.

Bali is a province that has several fishing ports, one of which is Nusantara fishing port Pengambengan and has a large enough marine fishery resource potential, especially in Jembrana Regency. This regency has a sea area of approximately $604.24 \mathrm{~km}^{2}$ and is the largest marine fish producer in Bali Province. The beach that stretches in the southern part of Jembrana Regency starts from Pengeragoan Village to the westernmost area, namely Gilimanuk. The residents who live along this coast rely on their livelihoods as fishermen, both traditional and semimodern. The sustainable potential of marine fishery resources in the waters of West Bali or Jembrana Regency is 56,947 tons per year [16].

The fishing port in Jembrana Regency is Pengambengan Class B Nusantara Fishery Port. The problems faced by Nusantara fishing port Pengambengan in fisheries management are currently very complex, starting from the limited human resources, a lack of human resources who really understand about fisheries management, some facilities with inadequate conditions and inadequate supporting infrastructure. To overcome this problem, it is necessary to formulate a strategy which in the future is expected to be used as a guide in the management of the fisheries sector and be able to attract investors to cooperate in developing fishing ports to improve class classification in this Pengambengan Nusantara fishing port later.

In the development plan to increase the class classification in Nusantara fishing port Pengambengan, it is necessary to evaluate the elements of facilities and operations which are very important to do, therefore the research plan regarding the Fishery Port Development Strategy Improving Class Classification at Pengambengan Fishery Ports condition of the facility and provide plans and plans for a development strategy to improve the classification of the pengambengan Nusantara fishing port class to class A later. 


\section{METHODS}

The method used in this research are descriptive qualitative and quantitative methods. This qualitative descriptive method aims to describe the behavior of people, field events, and certain activities in detail and depth, while the quantitative research method is said to be a method that emphasizes more on aspects of objective measurement of social phenomena. This research was conducted through direct observation and interviews using a questionnaire to determine the condition of the Pengambengan fishing port facilities as well as direct observations of objects in the form of basic facilities, functional facilities and supporting facilities at the Pengembengan Archipelago Port [26].

Determination of respondents in this study based on the population of Pengambengan fishing port. The population is a generalization area consisting of objects/subjects that have certain qualities and characteristics determined by researchers to be studied and then drawn conclusions [25].

The population in this study were all staff of fishing port Pengambengan employees and service users of fishing port Pengambengan with a total of 2,262 people. Based on the existing population, the sampling in this study was using the Taro Yamane or Slovin formula [23].

$$
n=\frac{N}{N d^{2}+1}
$$

Information

$\mathrm{n}=$ number of samples

$\mathrm{N}=$ number of population

$\mathrm{d}=$ precision or tolerance limit for sampling error $(0.1)$

From the calculation results through the formula above, based on the population of Nusantara fishing port Pengambengan 2,262 people, the results of the total sample size of 96 respondents have been determined.

Analysis of the data used in this research is SWOT analysis where SWOT Analysis consists of (Strengths, Weaknesses, Opportunities, and analysis Threats) is based on the logic that maximizes the strengths (Strengths) and opportunities (Opportunities) an activity can simultaneously minimize your weaknesses (Weaknesses ) and threats (Threats), this analysis is referred to as situation analysis. This analysis is further advanced as an analysis to examine internal and external conditions which are then combined to find a development strategy. In the SWOT analysis, the steps used by researchers to process data obtained in the field are carried out in a way, starting from determining the rating, determining weights, EFAS and IFAS matrix analysis, quadrant analysis, and matrix analysis [21].

\section{RESULT AND DISCUSSION}

\section{General Condition}

The Nusantara Fishery Port of Pengambengan is located at positions $08^{\circ} 23^{\prime} 46$ "LS and 114 $34^{\prime} 47^{\prime \prime}$ East Longitude, on the fishing port road no.1, Pengambengan Village, Negara District, Jembrana Regency, Bali Province. It is $9 \mathrm{~km}$ from Negara city and $105 \mathrm{~km}$ from Denpasar City, overlooking the Water Utilization Area fishery management area (WPP) 573 Indian Ocean and
713 Bali Sea. The sea area of the Pengambengan Nusantara Fishery Port is $20 \mathrm{Ha}$ and the land area of the Pengambengan Nusantara Fishery Port is $13.5 \mathrm{Ha}$.

Nusantara fishing port Pengambengan is the largest center of fisheries activities in west Bali and is the only domestic fishing port on the island of Bali which is utilized by fishermen from Bali and fishermen from the island of Java. The condition of Nusantara fishing port Pengambengan can be seen through the facilities contained in fishing port Pengambengan starting from basic facilities, functional facilities, and supporting facilities where some of these facilities are quite complete and are very good in supporting fishery activities at fishing port Pengambengan, but there are One of the main facilities that is not in good condition and is very prominent in Pengambengan fishing port is the condition of the anchoring facility which is silting up to the shipping channel. The beach around fishing port Pengambengan has many problems with high sedimentation due to the large amount of sedimentation on the left side of the breakwater, this is one of the causes of silting in the anchoring pond at fishing port Pengambengan. The condition of thepond anchoringat fishing port Pengambengan is currently very disruptive to ship traffic activities, ship mooring activities and loading and unloading of catches.

\section{Fleet and Equipment Fish}

Fleet and fishing gear at Pengambengan fishing port still use traditional vessels and still apply thesystem One Day Fishing. Pengambengan fishing port fishermen usually do not have their own boat, fishermen only work for the skipper / boat owner. The ships visiting fishing port Pengambengan are local ships owned by individuals from Jembrana Regency as well as ships from Banyuwangi / East Java. The fishing boats operating in waters Area East Java, Bali waters starting from Jembrana waters to the waters surrounding Jimbaran using purseseine/ trawlercircumference,gill nets and fishing stalling. The number of vessels in 2020 is 340 vessels, of which 5 GT boats / jukung are more than 6-30 GT vessels. The number of ship / boat fleet visits at Pengambengan fishing port can be an indicator of the level of operation at Pengambengan fishing port. The ship's fleet and fishing gear can be seen in Figure 1. on the graph in detail below.

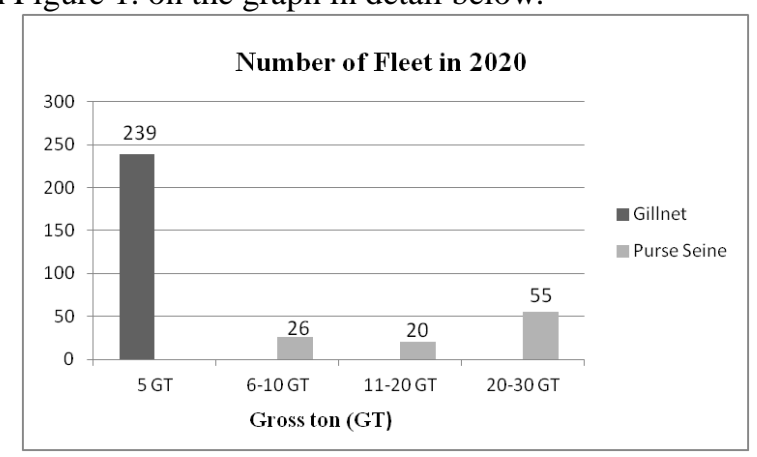

Figure 1. Number of Fleet in 2020 


\section{Catch Fish}

The catch that is usually landed at fish auction fishing port Pengambengan is the type of tuna (Euthynnus affinis), Lemuru (Sardinella), and Layang (Decapterus). The most dominant fish catch in 2019 is Lemuru (Sardinella) with a catch of 16,005 tons. Marketing The fish catch from fishermen is then used as raw material for canned fish and fish meal by fish processing companies / factories around fishing port Pengambengan and some of the catch is taken by collectors to be marketed around Jembrana Regency to East Java. detailed fish catch can be seen in Figure 2. below.

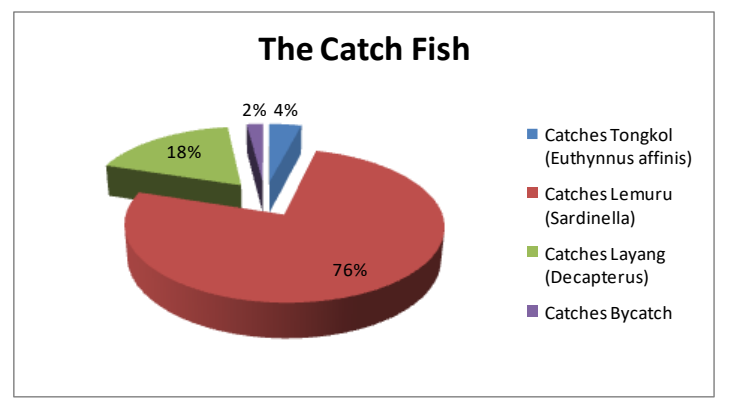

Figure 2. The Catch Fish

\section{Fishing Port Pengambengan Facility}

The facilities available at fishing port Pengambengan currently meet the criteria in the Minister of Marine Affairs and Fisheries Decree Number 08 / MEN / 2012 concerning fishing ports [9]. In general, the basic facilities, functional facilities, and supporting facilities available at fishing port Pengambengan are in quite good condition. The following can be seen in Table 1, namely the facilities contained in the fishing port Pengambengan in detail from the type, size and condition.

TABLE 1

PORT FACILITY

\begin{tabular}{lll}
\hline Basic facility & Size / Length & Condition \\
\hline Pier & $1,026 \mathrm{~m}^{2} / 171 \mathrm{~m}^{2}$ & Less Good \\
Jetty & $140 \mathrm{~m}^{2}$ & Good \\
Break water & $743 \mathrm{~m}^{2} /$ & Good \\
$884 \mathrm{~m}^{2}$ & Not Good / \\
Mooring Pond & $16 \mathrm{Ha}^{2}$ & Shallow \\
Groin & $1,026 \mathrm{~m}^{2} / 667 \mathrm{~m}^{2}$ & Good \\
The Street Complex & $13815 \mathrm{~m}^{2}$ & Less Good \\
Drainage & $1,738 \mathrm{~m}^{2}$ & Less Good \\
Barrier & $286 \mathrm{~m}^{2}$ & Good \\
Area mainland Port & $13.5 \mathrm{Ha}^{2}$ & Well \\
\hline
\end{tabular}

\begin{tabular}{|c|c|c|}
\hline $\begin{array}{l}\text { Facility } \\
\text { Functional }\end{array}$ & Area / unit & Conditions \\
\hline Port Office & $542.1 \mathrm{~m}^{2}$ & Prety Good \\
\hline Fish Auction & $1,525 \mathrm{~m}^{2}$ & Good \\
\hline Water supply & $74.5 \mathrm{~m}^{2}$ & Good \\
\hline $\begin{array}{l}\text { Ward / net repair } \\
\text { place }\end{array}$ & $251.7 \mathrm{~m}^{2}$ & Poor \\
\hline Cold Storage & $676.3 \mathrm{~m}^{2}$ & Good \\
\hline Fuel Oil & $36.6 \mathrm{~m}^{2}$ & Good \\
\hline $\begin{array}{l}\text { Electrical } \\
\text { installation }\end{array}$ & $230 \mathrm{Kva}$ & Good \\
\hline $\begin{array}{l}\text { Ice Flake Machine } \\
\text { (IFM) }\end{array}$ & $30 \mathrm{~m} 25$ ton / day & Good \\
\hline $\begin{array}{l}\text { Supporting } \\
\text { facilities }\end{array}$ & area of & Condition \\
\hline $\begin{array}{l}\text { Meeting hall } \\
\text { fishermen }\end{array}$ & $204.1 \mathrm{~m}^{2}$ & Good \\
\hline Mess been & $240 \mathrm{~m}^{2}$ & Good \\
\hline Mess Head Harbor & $65.4 \mathrm{~m}^{2}$ & Good \\
\hline $\begin{array}{l}\text { Places of Worship } \\
\text { Temple and small } \\
\text { mosque }\end{array}$ & $\begin{array}{l}148.32 \quad \mathrm{~m}^{2} / 142 \\
\mathrm{~m}^{2}\end{array}$ & Good \\
\hline Public Toilet & $34 \mathrm{~m}^{2}$ & Poor \\
\hline Stall & $288 \mathrm{~m}^{2}$ & Good \\
\hline Guard Post & $31 \mathrm{~m}^{2}$ & Good \\
\hline Post service & $54 \mathrm{~m}^{2}$ & Good \\
\hline Guest House & $127.5 \mathrm{~m}^{2}$ & Broken \\
\hline
\end{tabular}

The facilities available at Nusantara fishing port Pengambengan are currently very good in supporting fisheries activities at Nusantara fishing port Pengambengan, but there are several facilities that are not in good condition, namely the jetty which is currently in poor condition because there are still many roads on the pier with holes so that there is a pool of water on the pier. as well as the pillars at the foot of the pier, there are some porous concrete so that it looks iron on the frame of the pier leg. The anchoring pond is not good due to the silting of the anchoring pond as high as approximately $1.5 \mathrm{~m}$ which results in disruption of the mooring and mooring activities of vessels and loading and unloading of catches 
and vessels over 30 GT have not been able to enter Pengambengan Nusantara fishing port. The complex road is in poor condition because there are several parts of the complex road with holes so that it can interfere with the activities of fishermen and other staff with an interest in the port. Drainage is not in good condition, due to heavy rain, the area at Nusantara fishing port Pengambengan often experiences flooding / excessive standing water and will greatly disrupt the activities at the port. Public toilets are in poor condition due to lack of maintenance and hygiene in public toilets. Guest house with conditions not suitable for use because the facilities at the guest house are damaged. In addition, there are several facilities that are not yet available and very much needed at this time by the fishing community / users at Pengambengan Nusantara fishing port, facilities that are not yet available and are urgently needed at this time, namely boat docks, wards / places for repairing nets, laboratories, WWTPs, watchtowers, and perimeter fence.

Conditions for Technical and Operational Criteria for Nusantara fishing port Pengangambengan with Ocean Fishing Ports The

Conditions for technical and operational criteria in Nusantara fishing port Pengambengan can be compared with the conditions for technical criteria at class A ocean fishing ports (PPS) as stated in the Decree of the Minister of Marine Affairs and Fisheries Number 08 / MEN / 2012 concerning Fisheries Ports [9], states that the technical criteria for PPS are able to serve fishing vessels that carry out fishing activities in Indonesian waters, the Indonesian exclusive economic zone (ZEEI), to the high seas, while PPN pengambengan conducts fishing activities mostly in territorial waters up to ZEEI. PPS is capable of serving mooring and anchoring ships of at least 60 GT in size, while Nusantara fishing port Pengambengan is only able to serve fishing boats with a maximum size of 30 GT. PPS has a pier length of at least $300 \mathrm{~m}$, with a pool depth of at least minus $3 \mathrm{~m}$, while the length of the pier at Nusantara fishing port Pengambengan is $171 \mathrm{~m}$, with a depth of anchoring ponds exceeding minus 3.PPS utilizes and manages at least 20 ha of land, while Nusantara fishing port The new pengambengan uses an area of 7.6 ha. In addition, based on the above regulations related to operational criteria at PPS the catch which is partially landed for export purposes, while the Pengambengan Nusantara fishing port has not yet exported the catch. PPS is marketing fishery products for an average of 50 tons per day, while Nusantara fishing port Pengambengan gets fishery products up to 60 tons per day.

\section{Matrik IFAS and EFAS}

TABLE 2

Matrix IFAS (Internal Factor Analysis Summary)

\begin{tabular}{lccc}
\hline \multicolumn{1}{c}{ STRENGTH } & QUALITY & RATING & SCORE \\
\hline $\begin{array}{l}\text { Catches have good } \\
\text { quality. }\end{array}$ & 0.181 & 4 & 0.724 \\
\hline $\begin{array}{l}\text { Administrative } \\
\text { services provided } \\
\text { both to fishermen. }\end{array}$ & 0.179 & 4 & 0.716 \\
\hline
\end{tabular}

\begin{tabular}{|c|c|c|c|}
\hline $\begin{array}{l}\text { Condition of the } \\
\text { fish auction, the } \\
\text { supply of clean } \\
\text { water, fuel oil and } \\
\text { electrical } \\
\text { installations are } \\
\text { very supportive of. }\end{array}$ & 0.176 & 4 & 0.704 \\
\hline SUBTOTAL & 0.536 & & 2.144 \\
\hline WEAKNESS & QUALITY & RATING & SCORE \\
\hline $\begin{array}{l}\text { Swimming landing } \\
\text { is still shallow. }\end{array}$ & 0.128 & 4 & 0.512 \\
\hline $\begin{array}{l}\text { Pier and complex } \\
\text { way inadequate } \\
\text { (There is damage). }\end{array}$ & 0.162 & 3 & 0.486 \\
\hline $\begin{array}{l}\text { Public toilets and a } \\
\text { guest house less } \\
\text { attention. }\end{array}$ & 0.173 & 2 & 0.346 \\
\hline SUBTOTAL & 0.463 & & 1,344 \\
\hline TOTAL IFAS & 1 & & 3,488 \\
\hline
\end{tabular}

In Table 2, the IFAS matrix shows that the highest score on strength is the quality of the fish catch that is of good quality with a score of 0.724 as the main priority, while for weakness the highest score is the shallow anchoring pond with a score of 0.512 as the main priority. Among the subtotals on the strengths and weaknesses above the highest score is in the strength table with a score of 2.144. In the strategy of developing port class B to class A, fishing port Pengambengan shows that the strength factor is more influential than the weakness factor so that the strength factor can be used as the basis for decision and policy making.

TABLE 3

Matrix EFAS (Eksternal Factor Analysis Summary)

\begin{tabular}{|c|c|c|c|}
\hline OPPORTUNITY & QUALITY & RATING & SCORE \\
\hline $\begin{array}{l}\text { area of land that } \\
\text { can still be } \\
\text { utilized }\end{array}$ & 0.169 & 3 & 0.507 \\
\hline $\begin{array}{l}\text { Condition fleets } \\
\text { and fishing gear } \\
\text { are very } \\
\text { supportive. }\end{array}$ & 0.164 & 3 & 0.492 \\
\hline $\begin{array}{l}\text { The importance of } \\
\text { the role of } \\
\text { investors in the } \\
\text { construction and } \\
\text { development of } \\
\text { facilities that are } \\
\text { not available }\end{array}$ & 0.176 & 3 & 0.528 \\
\hline SUBTOTAL & 0.51 & & 1,527 \\
\hline THREAT & QUALITY & RATING & SCORE \\
\hline $\begin{array}{l}\text { Fishermen have } \\
\text { not fully complied } \\
\text { with the } \\
\text { applicable rules. }\end{array}$ & 0,154 & 3 & 0,462 \\
\hline $\begin{array}{l}\text { Lack of } \\
\text { assertiveness } \\
\text { supervision of the } \\
\text { fishing vessel. }\end{array}$ & 0.158 & 3 & 0.474 \\
\hline
\end{tabular}




\begin{tabular}{lcc}
\hline $\begin{array}{l}\text { People who have } \\
\text { no interest easily } \\
\text { enter the fishing } \\
\text { port area. }\end{array}$ & 0.178 & 2 \\
\hline SUBTOTAL & $\mathbf{0 . 4 9}$ & 0.356 \\
\hline TOTAL EFAS & $\mathbf{1}$ & $\mathbf{1 , 2 9 2}$ \\
\hline
\end{tabular}

In Table 3.The EFAS matrix shows the highest score on opportunity is the importance of the role of investors in the development and development of facilities that are not yet available with a score of 0.528 as the main priority, while the highest score for threat is the lack of strict supervision of fishing boats with a score 0.474 as the top priority. Among the subtotals on opportunities and threats above, the highest score is in the odds table with a score of
1.527. In the strategy of developing port class B to class A, fishing port Pengambengan shows that the opportunity factor is more influential than the threat factor so that the strength factor can be used as the basis for decision and policy making

\section{SWOT Analysis Matrix}

In the SWOT matrix analysis is a tool used to formulate strategic factors in Pengambengan fishing port. From the results of IFAS and EFAS calculations, it can be used as a reference for compiling a SWOT matrix. The preparation of the analysis matrix includes the Internal IFAS - External EFAS Matrix, which is to formulate a strategy that is divided into nine table boxes below:

TABLE 4.

Matrik Analisis SWOT

\begin{tabular}{|c|c|c|}
\hline IFAS & Strength $(\mathbf{S})$ & Weakness (W) \\
\hline EFAS & $\begin{array}{l}\text { 1. Good administrative services for } \\
\text { fishermen. } \\
\text { 2. The quality of the fish catch is of } \\
\text { good quality. } \\
\text { 3. Condition of the fish auction, the } \\
\text { supply of clean water, fuel oil and } \\
\text { electrical installations are very } \\
\text { supportive of }\end{array}$ & $\begin{array}{l}\text { 1. The still shallow mooring pond. } \\
\text { 2. Inadequate wharves and complex } \\
\text { roads (Damaged). } \\
\text { 3. Public toilets and guest houses that } \\
\text { don't get enough attention. }\end{array}$ \\
\hline Opportunity (O) & SO & WO \\
\hline $\begin{array}{l}\text { 1. The area of land that can still be } \\
\text { used. } \\
\text { 2. The condition of the fleet and } \\
\text { fishing gear is very supportive. } \\
\text { 3. The important role of investors } \\
\text { in the construction and } \\
\text { development of facilities that } \\
\text { are not yet available. }\end{array}$ & $\begin{array}{l}\text { 1. Improve the quality of the catch in } \\
\text { order to provide a positive image } \\
\text { for potential investors. } \\
\text { 2. Improve administrative services to } \\
\text { provide fishermen comfort when } \\
\text { carrying out fishing operations. } \\
\text { 3. Support is needed, especially the } \\
\text { role of the government related to } \\
\text { management and development. }\end{array}$ & $\begin{array}{l}\text { 1. Repair of the anchorage pond is } \\
\text { dredged to maximize depth and } \\
\text { expand the anchor pond. } \\
\text { 2. Repairs to the jetty and complex } \\
\text { roads for the convenience of fishing } \\
\text { communities when carrying out } \\
\text { activities. } \\
\text { 3. Pay more attention to inadequate } \\
\text { facilities. }\end{array}$ \\
\hline Threat (T) & ST & WT \\
\hline $\begin{array}{l}\text { 1. Fishermen have not fully } \\
\text { complied with the applicable } \\
\text { rules. } \\
\text { 2. Lack of strict supervision of } \\
\text { fishing vessels. } \\
\text { 3. People who have no interest } \\
\text { easily enter the fishing port area. }\end{array}$ & $\begin{array}{ll}\text { 1. } & \begin{array}{l}\text { Provide advice and counseling } \\
\text { regarding work safety rules. }\end{array} \\
\text { 2. } & \begin{array}{l}\text { Take decisive action under } \\
\text { surveillance. }\end{array} \\
\text { 3. } & \text { Installation of a perimeter fence. }\end{array}$ & $\begin{array}{l}\text { 1. Doing dredging the anchoring } \\
\text { pond regularly and regularly. } \\
\text { 2. Give sanctions to officers who } \\
\text { grant sailing permits to ships that } \\
\text { do not have complete documents. } \\
\text { 3. Strengthening security officers } \\
\text { and checking when entering the } \\
\text { fishing port area. }\end{array}$ \\
\hline
\end{tabular}

\section{SWOT Analysis Quadrant}

The calculation results of the IFAS and EFAS matrices / internal factors and external factors get the total score of internal factors of 3.488 while the total score of external factors is 2.819 . It can be seen that the highest score among the 2 total score factors is the highest score in internal factors where internal factors. Having a higher score than external factors, it can be concluded that the internal factors that will be more influential in the port 
development strategy are increasing the class classification of Nusantara fishing port Pengambengan.

It can be seen in the IFAS / EFAS matrix table that the internal and external factors in the table are obtained subtotal scores on the factors of strengths, weaknesses, opportunities, and threats, namely:

1. Total score of the strength factor $: 2,144$

2. Total score of weakness : 1,344

3. Total score by the odds factor : : 1,527

4. The total score of the threat factors : 1,292

From the results of the calculation of internal factors and external factors, these will be used to determine the SWOT quadrant, in the SWOT quadrant there is a vertical $\mathrm{x}$ axis and a horizontal $\mathrm{y}$ axis, where the vertical $\mathrm{x}$-axis contains strength and weakness factors, while on the y-axis horizontally there are opportunities and threats. The calculation is obtained from the difference in the total score of the strengths and weaknesses for the $\mathrm{x}$-axis, while the difference in the total score of the opportunity and threat factors for the y-axis. This calculation can be seen below, namely as follows:

TABLE 5.

The Results of The SWOT Quadrant Calculation

\begin{tabular}{cc}
\hline $\begin{array}{c}\text { Sum of scores for } \\
\text { Internal Factor }\end{array}$ & $\begin{array}{c}\text { Sum of scores for } \\
\text { External Factor }\end{array}$ \\
\hline 2,144 & 1,527 \\
1,344 & 1,292 \\
\hline $\mathrm{x}=0,800$ & $\mathrm{y}=0,235$ \\
\hline
\end{tabular}

The results of the coordinate values obtained in the SWOT quadrant in table 5 above are $(0.800 ; 0.235)$ for the Port Development Strategy to increase the class classification on Pengambengan Nusantara fishing port. The coordinates of the SWOT quadrant can be seen in the image below:

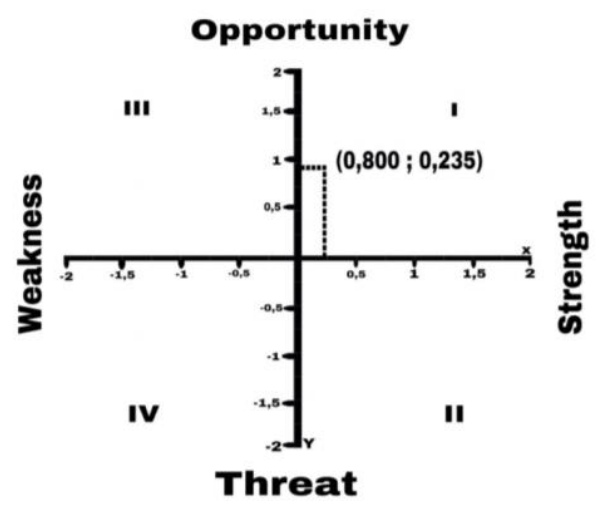

Figure 3. SWOT Analysis Quadrant

In the SWOT quadrant image above shows that the port development strategy to improve class classification in Nusantara fishing port Pengambengan is in quadrant I, so the strategy in question is the strength that is owned by Nusantara fishing port Pengambengan must be able to take advantage of existing opportunities, strategies that must be applied in this condition, namely the strength and opportunity strategy ( $\mathrm{SO}$ ) creates a strategy that uses strength to take advantage of opportunities. This strategy indicates that the Pengambengan Nusantara fishing port is strong and able to continue to grow by taking the existing opportunities or opportunities to achieve maximum increase. The strategy obtained is the SO strategy where the SO strategy has been predetermined in table 4 of the SWOT analysis matrix above, with the following strategies: (1) Improving the quality of the catch in order to provide a positive image to potential investors. (2) Improve administrative services in order to provide fishermen comfort when carrying out fishing operations. (3) Support is needed, especially the role of the government related to management and development.

The development strategy increases the Class B to Class A fishing port classification.

From the results obtained through the SWOT quadrant analysis, the numerical results indicate that the port development strategy to improve class classification in the Pengambengan Nusantara fishing port is in quadrant I, namely the strategy used is the SO strategy where this strategy uses strength to take advantage of opportunities. SO strategy is a strategy used by companies by utilizing or optimizing the strengths (S) they have to take advantage of various opportunities $(\mathrm{O})$ [6]. Below are the SO strategies that have been determined as follows:

1. Improving the quality of the quality of the catch in order to provide a positive image to potential investors.

Based on the results of interviews and observations in the field, the quality of the catch quality at the Pengambengan Nusantara fishing port is currently quite good, but it is necessary to pay attention to the handling carried out when loading and unloading the catch has not been fully implemented properly, the loading and unloading process of the caught fish is carried out through the anchorage pond water incorrectly. Fish that land directly at the Nusantara fishing port Pengmbengan fish auction will be contaminated by the waters of the anchorage pond which will result in a decrease in the quality of some of the fish caught. The handling of the catch must be done quickly so that there is no change in temperature which will result in a decrease in the quality of the fish. Handling the caught fish properly will determine the quality of the fish so that the price of fish will be higher [2].

By improving the quality of the catch quality at Nusantara fishing port Pengambengan, it can be noticed again how to handle the loading and unloading of the catch so that it does not pass through the anchorage pond, this is because the anchor pond is experiencing siltation, the fishing vessel that will carry out the loading and unloading process of the catch is blocked and cannot enter to the edge of the pier. The docking pond at the Nusantara fishing port Pengmbengan must be dredged so that the fishing vessel that will carry out the loading and unloading process of the catch can be carried out on the edge of the pier with the handling of loading and unloading of the catch which will be more effective and faster, so that indirectly the quality of the catch at the Nusantara fishing port Pembengan will be far better.

Increasing the quality of the catch will indirectly attract the attention of potential investors who will invest their business capital in Nusantara fishing port Pengambengan 
and will be able to use the remaining land to build a fishery business or build facilities that are not yet available later. In carrying out investment activities, every investor/investor pays more attention to the quality of goods produced by a company and the success rate of opportunities for marketing an item, it is undeniable that investors will be very interested in investing if the goods produced in a company have selling quality. good [22]. Cooperation with investors to strengthen business capital has a major impact on the sustainability of the development of a fishing port [7].

2. Improve administrative services to provide fishermen comfort when carrying out fishing operations.

Based on the results of interviews and observations of administrative services at Nusantara fishing port Pengambengan, it needs to be improved again in terms of administrative facilities, especially work support facilities and infrastructure that must be improved, especially computers and applications in them must be updated so that they are not too late to find out information related to the service process for taking care of letters. ships, reporting to the center with more instant access and delivering information to fishing communities quickly. The services provided by the port are generally administrative services related to the management of ship permits, so that in the end they can meet the needs of port users, especially satisfaction for fishermen which will greatly affect performance and catches [4].

With the increase in administrative services at Nusantara fishing port Pengambengan will provide convenience for fishermen, especially in carrying out fishing operations at sea. After receiving the best service, it will indirectly stimulate prospective fishing boat entrepreneurs to carry out fishing business activities at the Pengambengan Nusantara fishing port later and it is hoped that more modern types of vessels and fishing gear will be added at the Pengambengan Nusantara fishing port. The addition of more modern types of fishing gear and fishing fleet units will increase fishing reach, increase fishing effort (number of trips) and become more diverse and increase catches [1]. From the results of the fishery business, one of the most expected is to obtain high business profits, which will be very influential in the development of a fishing port later [7].

3. Support is needed, especially the role of the government related to management and development.

Carrying out a fishing port development, the central government's participation in managing and developing infrastructure/facilities at Nusantara fishing port Pengambengan is very much needed. The criteria for the carrying capacity of the development of a PP are the aspirations of the central and local governments [11]. The current Pengambengan Nusantara fishing port really needs the support of the central government in constructing facilities that are not yet available, from the results of observations and interviews in the field, the facilities needed for the current Pengambengan Nusantara fishing port namely ship docking, wards/network repair sites, laboratories, WWTPs, control towers, and perimeter fences. In addition, facilities that greatly interfere with ship activities and loading and unloading activities at Nusantara fishing port Pengambengan are very shallow anchorage pools, it is hoped that this will become a priority The main priority by the central government will be to carry out routine dredging of the anchorage pond.

Regarding the management of the Pengambengan Nusantara fishing port, it is hoped that it will not only be managed by the local government/central government but can also be managed by Indonesian fishing companies such as Perindo and Perinus. Fishing ports are usually for construction of fascia litas is still carried out by the central government, but the management system is only given to public companies that have been appointed and trusted by the central government. In Indonesia, there are several fishing ports that have been commercialized to be managed by the Indonesian Fisheries Public Company (Perum Perindo). Its have been implemented in six fishing ports among of them, Nizam Zachman Ocean Fishing Port Jakarta, Belawan Ocean Fishing Port, Pekalongan Nusantara Fishery Port, Brondong Nusantara Fishery Port, Nusantara Fishery Port in Pemangkat, and Prigi Nusantara Fishery Port. It is hoped that the Pengambengan PPN can be managed together with the Indonesian fishery public company as previously mentioned. After the management and development, it is expected that the PPN pengembengan will experience an increase in status, which is currently the class B Nusantara Fishery Port to be a class A fishing port, namely the Ocean Fishery Port [20].

\section{CONCLUSION}

Based on the research conducted at Nusantara fishing port Pengambengan regarding port development strategies to improve class classification in PPN Pengambengan, the following conclusions can be drawn:

1. The condition of the facilities at the Pengambengan Nusantara fishing port in general has met the criteria as stated in the Decree of the Minister of Maritime Affairs and Fisheries Number 08/MEN/2012 concerning fishing ports and with all facilities having a fairly good condition in supporting fisheries management activities at the Pengabengan Nusantara fishing port. However, there are several facilities with unfavorable conditions at the Pengambengan Nusantara fishing port, namely the basic facilities of the dock, anchorage pool, complex road and drainage, from the supporting facilities, namely public toilets and guest houses. There are several facilities that are not yet available and are urgently needed in the Nusantara fishing port Pengambengan for vetting, namely ship docking, wards/net repair sites, laboratories, WWTPs, control towers, and perimeter fences.

2. The port development strategy to improve class classification in Nusantara fishing port Pengambengan based on the results of the SWOT analysis shows that in quadrant I, the strategy in question is that the strengths possessed by Nusantara fishing port Pengambengan must be able to take advantage of existing opportunities, the strategy that 
must be applied in this condition is the strength and opportunity strategy ( $\mathrm{SO}$ ) creating strategies that use strengths to take advantage of opportunities. The strategy that can be taken is to improve the quality of the catch in order to provide a positive image for potential investors. Improve administrative services to provide fishermen comfort when carrying out fishing operations. Support is needed, especially the role of the government related to management and development.

\section{ACKNOWLEDGE}

The author expresses his deepest gratitude to the Faculty of Marine and Fisheries, Udayana University, then to the fishing port Pengambengan who has given permission to conduct this research, especially to the head of the port, staff/employees, the fishing community of fishing port Pengambengan which has helped the author. in the process of collecting data/information related to this research, as well as supervisors and other parties who have helped a lot in compiling this research.

\section{REFERENCES}

[1] Damayanti, HO 2018. Strategy for Traditional Fishing Business Development: A Case Study in Pecangaan Village, Batangan District, Pati Regency. Journal of Social Policy KP. 8(1) : 13-26

[2] Deni, S. 2015. Characteristics of Fish Quality During Handling on Ships KM. skipjack. UMMU-Temate Agricultural Scientific Journal. 8(2) : 72-80.

[3] Ministry of Marine Affairs and Fisheries, 2009 Article: Targets of the Ministry of Maritime Affairs and Fisheries 2014. 1 p. http:// www.dkp.go.id/Ministry of Marine Affairs and Fisheries of the Republic of Indonesia. htm. Accessed: February 12, 2009.

[4] Diniah., Sobari, MP, Seftian, D. 2012. Archipelago Fishery Port Services (PPN) for Fishing Operations Needs. Journal of Marine and Fisheries SocioEconomic Policy. 2(1):41-49.

[5] [DJPT] Directorate General of Capture Fisheries. 2009. Capture Fisheries Build the Nation. Performance 2008 and Outlook 2009. Jakarta. Ministry of Marine Affairs and Fisheries. 106 pp.

[6] Febrianto R, K., Mudzakir A K., and Rosyid A. 2015. Capacity Building for Functional Facilities Through the Minapolitan Program at the Nusantara Fisheries Port (PPN) Pekalongan, Central Java. Journal of Social Policy KP. 5 (2) : 89-100.

[7] Imelda., Kusrini, N., Hidayat, R. 2019. Strategy for Sustainable Capture Fisheries Management in the Coastal Area of Kubu Raya Regency. Journal of Marine Fisheries. 10(1) : 59-69.

[8] Jaya, I., Kurnia, M., Firman. 2017. Conditions and Analysis of Possible Development of Ternate Archipelago Fishery Port Facilities (PPN). PSP Science and Technology Journal. 4(7) : 49-60.

[9] Ministry of Marine Affairs and Fisheries, 2012, Decree of the Minister of Marine Affairs and Fisheries of the Republic of Indonesia No.
/Men/2012 concerning General Guidelines for Institutional Growth and Development of Fisheries Main Actors, Ministry of Maritime Affairs and Fisheries, Jakarta.

[10] Lubis E. 2011. A study of the strategic role of marine fishing ports on marine fisheries development. Aquatic Journal of Aquatic Resources. 5(2):1-7.

[11] Lubis E. 2012. Fisheries Port Book. Bogor (ID): IPB Press.

[12] Minister of Maritime Affairs and Fisheries. 2012. Regulation of the Minister of Marine Affairs and Fisheries NUMBER PER. 08/MEN/2012 concerning Fishing Ports. Jakarta (ID): Ministry of Marine Affairs and Fisheries.

[13] Moleong, LJ 2011. Qualitative Research Methodology Revised Edition. Bandung: PT Pemuda Rosdakarya.

[14] Mukhtar. 2013. Qualitative Descriptive Research Methods. Jakarta : GP Press Group

[15] Noviyanti, R. 2011. Conditions of capture fisheries in Indonesian fisheries management areas (WPP). Open University, Jakarta. accessed on 7 June 2013.

[16] Government of Jembrana Regency, 2015. Profile of the Department of Marine Affairs, Fisheries and Forestry 2014. Jembrana. 97-102 pp.

[17] Minister of Marine Affairs and Fisheries Regulation Number 71/Permen-KP/2016 concerning Fishing Paths and Placement of Fishing Equipment and Fishing Aids in the Fisheries Management Area of the Republic of Indonesia, Recommendation from the Ombudsman of the Republic of Indonesia, (June 2015) Director General of PSDKP Letter No. 14319/DJPSDKP/IX/2015

[18] Priyambodo. 2012. Port Development in Pasuruan City. Journal of Marine Transportation Research. 14(1) : 77-89.

[19] Rahmawati, W., Suryono, A., Siswidiyanto. 2014. Development of Fishery Ports in the Plan for Absorption of Coastal Communities (Study at the Brondong Archipelago Fishery Port Office, Lamongan Regency). Journal of Public Administration (JAP). 2(2) : 367-373

[20] Rahmayanti, A, Z. 2018. The Role of Government and Private in Provision of Capture Fisheries Infrastructure: Bitung Case Study. Journal of Economics and development. 26(2) : 131-141.

[21] Rangkuti, F. 2017. SWOT Analysis of Business Case Dissecting Techniques. Jakarta: Gramedia Pustaka Utama.

[22] Rares, W, N. 2013. Responsibilities of investors in Investment in Indonesia. Scientific Journal of Efficiency. 1(3) : 68-76.

[23] Riduwan. 2005. Easy Learning Research for Teacher-Employees and Beginner Researchers. Bandung : Alphabeta. p. 65.

[24] Rionaldi. 2014. Analysis of Location Selection and Strategic Management of Sea Port Development in Riau Province. Communication Research News. 26(8) : 477-485 
[25] Sugiyono. 2010. Educational Research Methods Quantitative, Qualitative, and R\&D Approaches. Bandung: Alphabeta

[26] Sugiyono. 2012. Qualitative Quantitative Research Methods and R\&D. Bandung: Alphabeta. p. 117.

[27] Suherman, A. 2010. Alternatives to the Development of the Brondong Archipelago Fishing Port, Lamongan, East Java. Journal of Fisheries Science. $5(2): 65-72$.

[28] Suherman, A. 2011. Formulation of the Archipelago Fishery Port Development Strategy of Pengambengan Jembrana. Journal of Marine Fisheries. 2(1) : 87-99.

[29] Sulistyono Y. 2015. Analysis of the Development of Functional Facilities and Ecoport Supporting Facilities at PPP Bajomulyo, Pati, Central Java
[Thesis]. Faculty of Fisheries and Marine Science. Diponegoro University, Semarang. $161 \mathrm{pp}$.

[30] Takdir, R, A., Buana, G, N, S. 2019. Analysis of Kendari Port Development Strategy. Wave Journal. 13(1) : 17-24.

[31] Triatmodjo, B., 2010, Port Planning, Beta Offset, Yogyakarta.

[32] RI Law Number 45 of 2009 concerning Amendments to Law Number 31 of 2004 concerning Fisheries. 